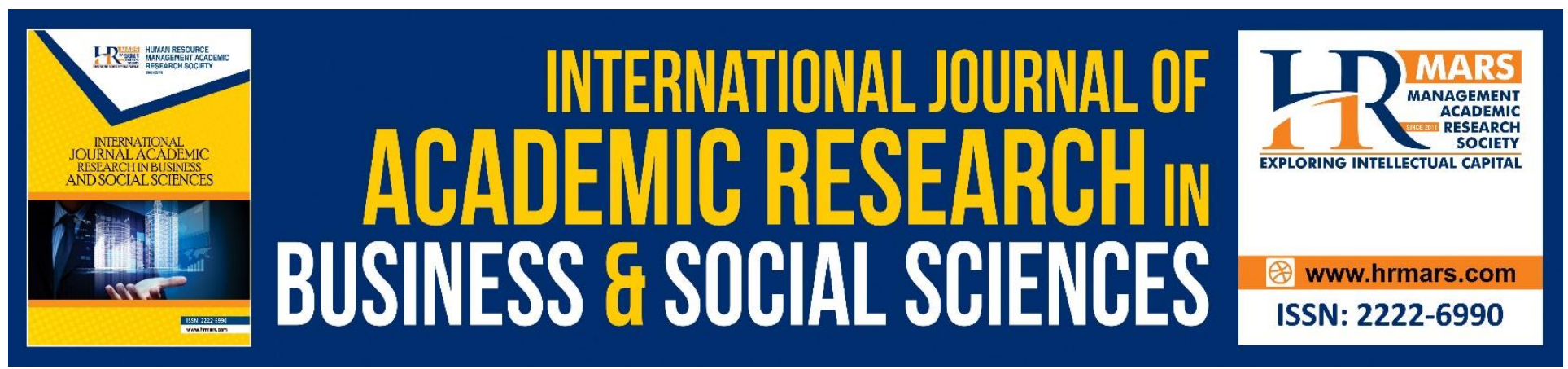

\title{
The Review of Effectiveness Integration Programs to Reduce Crime in Malaysia
}

Jessica Ong Hai Liaw, W.L Wong, Inderjit Singh Tara Singh, Ahmad Azan Ridzuan, Abdul Hamid Moiden, Norlaila Mazura Mohaiyadin, Abdul Sadat Abdu Rahiman

To Link this Article: http://dx.doi.org/10.6007/IJARBSS/v9-i1/5866 DOI: $10.6007 /$ IJARBSS/v9-i1/5866

Received: 02 Jan 2019, Revised: 17 Jan 2019, Accepted: 15 Feb 2019

Published Online: 24 Feb 2019

In-Text Citation: (Liaw et al., 2019)

To Cite this Article: Liaw, J. O. H., Wong, W. L., Singh, I. S. T., Ridzuan, A. A., Moiden, A. H., Mohaiyadin, N. M., \& Rahiman, A. S. A. (2019). The Review of Effectiveness Integration Programs to Reduce Crime in Malaysia. International Journal of Academic Research Business and Social Sciences, 9(1), 1353-1361.

Copyright: (C) 2019 The Author(s)

Published by Human Resource Management Academic Research Society (www.hrmars.com)

This article is published under the Creative Commons Attribution (CC BY 4.0) license. Anyone may reproduce, distribute, translate and create derivative works of this article (for both commercial and non-commercial purposes), subject to full attribution to the original publication and authors. The full terms of this license may be seen

at: http://creativecommons.org/licences/by/4.0/legalcode

Vol. 9, No. 1, 2019, Pg. 1353 - 1361

http://hrmars.com/index.php/pages/detail/IJARBSS

JOURNAL HOMEPAGE

Full Terms \& Conditions of access and use can be found at http://hrmars.com/index.php/pages/detail/publication-ethics 


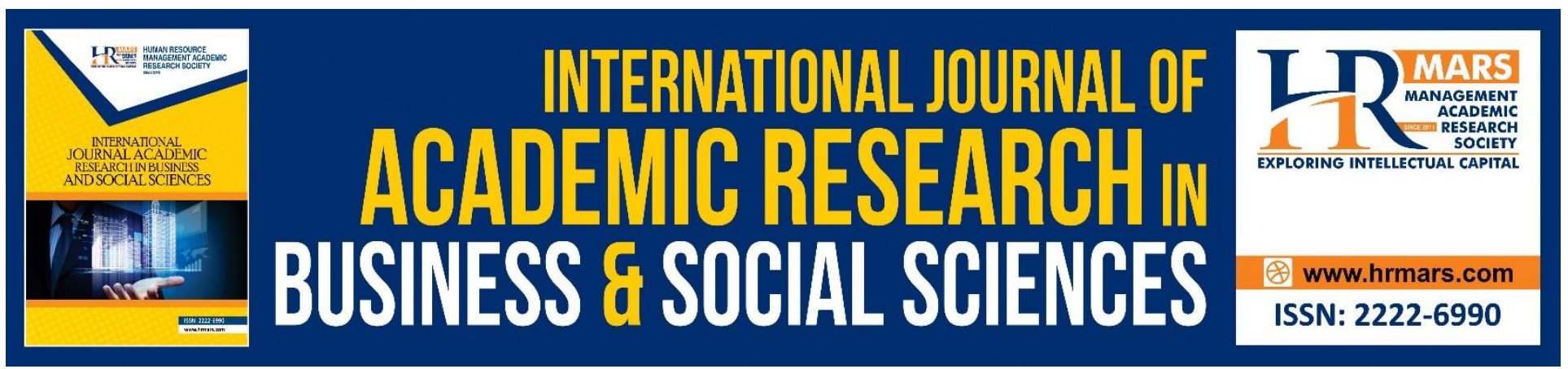

\title{
The Review of Effectiveness Integration Programs to Reduce Crime in Malaysia
}

\author{
Jessica Ong Hai Liaw, W.L Wong, Inderjit Singh Tara Singh, Ahmad \\ Azan Ridzuan, Abdul Hamid Moiden, Norlaila Mazura Mohaiyadin
}

Faculty of Defence Studies and Management, National Defence University of Malaysia, Sungai Besi Camp, 57000 Kuala Lumpur, Malaysia.

\author{
Abdul Sadat Abdu Rahiman \\ Markas Angkatan Tentera Malaysia, Bahagian Operasi Latihan Pertahanan, Kementerian \\ Pertahanan, 50634, Kuala Lumpur.
}

\begin{abstract}
This paper is to review the effectiveness of integration programs between the Royal Malaysian Police (RMP), Malaysian Armed Forces (MAF) and the Jabatan Perpaduan Negara dan Integrasi Nasional (JPNIN) to reduce the crime index for the residential area in Malaysia. The government has announced the Six National Key Result Areas (NKRA) policy with visions to reduce crime rates, to fight corruption, to provide affordable quality education, to improve the value of life, to enhance the infrastructure in rural areas and to upgrade transport links. The Malaysian government has taken an integrated and systematic approach. First, the community needs to reduce the number of serious criminal cases such as burglary. Second, public awareness should be enhanced by encouraging their participation as volunteers. Third, by using a fair and a collective criminal system can strengthen the good organization in terms of enforcement, especially the RMP, then the public confidence will be achieved. As part of these efforts, the crime laboratory has conducted workshops with the participation of more than 30 government agencies with selected non-governmental organisations (NGOs). In order to ensure resource sharing, collaboration and responsibility, the goals of GTP is not only to reduce crime rates, but the contributions to minimise the government's budgets by avoiding building new facilities.
\end{abstract}

Keywords: Crime, Security, Strategy, Awareness, Integrated

Introduction

The National Blue Ocean Strategy (NBOS) is introduced by the Prime Minister of Malaysia in 2009 which envisions toward the betterment of the nation through higher learning and improved citizen 
INTERNATIONAL JOURNAL OF ACADEMIC RESEARCH IN BUSINESS AND SOCIAL SCIENCES Vol. 9, No. 1, Feb, 2019, E-ISSN: 2222-6990 @ 2019 HRMARS

visions, to help Malaysia to become a country with high income and greater public well-beings.(The Blue Ocean Strategy Team, 2015).

There are 80-bureau sand agencies collaborate in this programs in order to evolve and execute and innovative and transformative strategy of NBOS for the country. (Ministry of Finance, 2014). W. Chan Kim and Renée Mauborgne are the professors who have initiated the idea of NBOS. NBOS or Strategi Lautan Biru, provides an inventive and methodical method in crafting a significance way at a small budget. NBOS is an approach mooted by the Prime Minister as a mean of achieving Government Transformation Programme.

The collaboration between police and military to reduce crime rates and increase security is among the first list of initiatives in NBOS. The military also conducts cooperative patrols with the police which is called Rondaan Awam Polis DiRaja Malaysia dan Angkatan Tentera Malaysia 1Malaysia (RAPAT $1 M$ ) in strengthening safety and security in high-crime zones as well as residential areas. This cooperative patrols which is coordinated by the military police, involve the members of Kawasan Rukun Tetangga (KRT) in sinking crime activities and crime rate aegis. On top of the RAPAT 1M, a successful rehabilitation programme for adolescence problematics or child delinquents at the Armed Forces bases, is another initiative under NBOS. The proportion of recidivism is reported almost zero after the courses (NBOS, 2015).

In order to increase social cohesion and national unity, a number of community programs are executed to strengthen public incorporation, foster an essence of forbearance and a greater union between Malaysia citizens. JPNIN has conducted approximate 875,500 collaboration actions with social organizations and programs such as Rukun Negara, Rukun Negara Secretariat, Community Integration, Social Networking, Cross Cultural and Inter-Religious Understanding. (Abdul Sadat, 2016).

\section{Literature Review}

The enforcement of monitoring programs in the neighbourhood in Malaysia has started up in Bangsar and Cheras, in collaboration with the Malaysian Crime Prevention Foundation (MCPF). Projects include a centralised control system (Central Monitoring System, CMS is installed on a variety of closed-circuit cameras (CCTV) in strategic locations. This concept also suggests that volunteers to serve the community crime preventive participation. Although the Malaysia crime index came down by $40 \%$ over the last five years (Khan, 2015). It is still a serious scenario. Since one of the National Key Result Areas (NKRAs) is to reduce crime rates, and hence it is crucial for Malaysia to become a fully developed country (Menteri, 2009).

Crime nd the fear of crime has tremendous impacts on the quality of life; sometimes it is accompanied with devastating effect and also has a substantial economic cost (Harun, 2005). In this respect, the Government is dedicated to reduce the crime rates in the country. Thus, there are 11,757 new PDRM recruits, a new Police Headquarters is built, including a new block for IPK Perlis and Police Stations as well as to strengthen the PDRM patrol through the purchase of 1,000 units of motorcycles for this purpose. RM121 millions is allocated for PDRM to implement various programs under NKRA 
INTERNATIONAL JOURNAL OF ACADEMIC RESEARCH IN BUSINESS AND SOCIAL SCIENCES Vol. 9, No. 1, Feb, 2019, E-ISSN: 2222-6990 @ 2019 HRMARS

policy. Furthermore, a sum of RM117 millions of allocation for the People's Volunteers Corps or Jabatan Sukarelawan Malaysia (RELA) improve and strengthen their roles which involves training and capacity building. It is a huge amount of allocation for the efforts in reducing the crime rate vision. However, although the Malaysia crime index has (Khan, 2015).

In recent years, the rising crime rate to a debate in Malaysia. The rate of increase in the crime rate is believed to be supported by some factors such as the cost of living, social problems and the rate of foreign workers in the country. (Amin Rahim, Rahim \& G.A, 2014) new programs typically begin or terminate the broadcast by saying the crime activities are involved the Malaysian citizens and foreigner. Apart from the efforts made by the Royal Malaysian Police (PDRM), articles in newspapers and the Internet continued highlighted a crime as the most threatening issues in Malaysia. In the year 2011, the increasing of public security sub-index almost 11.0 points for the previous year. This is being believed effected by decreasing crime activities. The calculation is based on 1000 populaces. This statistic has been published by Based on the Quality of Life Report 2011 released by the ETP in Quality of Life Report 2011. The numbers of crime declined by 12.0 percent from 712 cases per 100,000 people to 628 cases in 2011, most likely due to the continuous efforts were undertaken to reduce the crime rate (Economic Planning Unit, 2012). Related to the latest report, the importance of determining whether the picture and estimates expressed are a reflection of actual crime and dissemination of information beyond the reputation, particularly from an angle of perceived crime anxiety and the solution for this problem need serious attention and prevention. Furthermore, the statistics for crime index reported by the publication of the Performance Management and Delivery Unit (PEMANDU, 2013) in the first quarter of 2012 compared to 2013 also showed a reduction in the crime rate in Malaysia.

The crime index in the period January to June 2012 amounted to 76, 247 cases were reported. This number decreased by 2,120 cases to 74, 127 cases in 2013 (Sukumaran, 2013). In fact, the percentage reflected "no change" thus increasing the pressure and public concern about the growth in crime. Apart from a limited study in the country, only some information presented in the local paper about the rate of violent crime. Comparison between two to five years in the crime rate may not be representative of the overall scenario of violent crime in Malaysia - which has been commonly used to compare changes in crime trends. Absolute restriction imposes on the study has disabled the researcher to focus on the nature of violent crimes (e.g., homicide, burglary, sexual offences), venue of the occurrences and other additional information (e.g., gender, ethnicity) or about the victim and the offender. Still, many still do not know about the crimes of terrorism in this country before. In general, epidemiological knowledge about the incidence of violent crime in Malaysia is not enough. Such knowledge will enable a better understanding of the crime of terrorism in Malaysia, in particular, the weakness of the issues and the choice of target. Also, the detailed trend in violent crime and victimisation rates can provide input regarding the investigation of the case and, most importantly, allows intervention in social crime prevention efforts.

In order to analyses the correlation between police visibility and fear of crime, Salmi, Gronroos \& Keskinen (2004) in a definite and detailed form has rarely been studied as a potential factor affecting the fear of crime, although the most has pointed out frequent interaction between citizens and police is likely to be when citizens see the police. The study found that a mere act for the police, such as stepping out of the car now and then, not only in crime-related situations, has a 
positive impact on the fear of crime as expressed by the public. The rate of safety is high in the community that enforces the community policing, and the role of community policing is significant in solving the problem due to security. Police visibility can be defined to different meaning such as police patrols in the neighbourhood, police interaction through the phone with resident for information and the police are carrying out the task of implementing the law. Patrol activity was seen as particularly duty police indicating the police presence in the community. Patrolling activities is one of the factor that contributed to the lowering the crime rate and also reduce the community's worry and fear of crime. Residential areas that patrols by police believed that the crime rate reduce compare with areas that are not involved in patrols by the police. Study found that the withdrawal of police patrols of the neighbourhoods have led to an increase in fear. There are also studies that found that street patrols by police is more efficient to reduce the fear of crime than patrolling on motorcycles and cars.

Neighborhood's patrols introduced in the '80s due to the report of the police integrity and also represent duties and responsibilities of the police to maintain security. Neighbourhood patrols symbolise the cooperation between police other agencies and the community. The aimed is to prevent the crime with the new strategies and in the same time to reduce the fear of crime in the community and residential area. It is also aimed in improving the quality of life, reduce the levels of social disruption, and reduce the fear of crime. Neighborhood's patrols have contributed to a decrease in the level of fear of crime. This is due to several factors such as increasing neighbourhoods patrols presence among the people can improve confidence and reduce fear.

Public confidence to trust the police with police and community involvement can improve the satisfaction of contributing to society and less fear of crime. Also when the neighbourhoods patrols are involved with the community through community groups, activities of youth, school, etc. This collaboration fosters real connections between the neighbourhoods patrols plus the citizens, thereby reducing the level of fear that the people of this exhibition. Finally, because the neighbourhoods patrols are using innovative strategies under community control, which aims to reduce crime and disorder, overcoming these problems and restore civility to the neighbourhood that is also expected to affect fear.

\section{Crimes in Malaysia}

The RAPAT 1M Program between Police, Armed Forces and JPNIN in reducing crime in Malaysia, where criminal activities are high. Although it is vital to reduce the crime rate in Malaysia, studies regarding the matter are rather limited and published research materials are insufficient. (Habibullah, 2009). In this context, the results suggest that an inverse connection between crime rates and good governance in Malaysia to be implemented. Hence, good governance will reflect lower rates of criminal activities in Malaysia.

SCMS enables the RMP to evaluate the achievement of crime preventive measure applied by the local authorities and simultaneously identified crimes hot spots for closer monitoring. The system is currently used by 51 police stations and 12 municipal councils. By end of 2012, the system is used by 254 police stations. Its primary objective is to create a collaborative platform where agencies could work together to reduce crimes by sharing information through a user-friendly web portal. Additionally, since the system helps translate crime data into digital maps, the police could shift away from using pin maps to help them visualise crime information. He added that, "Pin maps, most of the 
time, are not permanent and have the tendency to be discarded and changed over time which makes doing a trend analysis of crime quite a tedious task. This situation also encourages local authorities to develop their own GIS crime mapping tools which are often very expensive to develop." In order to address this concern, the FDTCP integrates the SCMS and RMP's reporting system, in creating an online tool for crime reporting which linked the nation police stations. (Badariah \& Baharom, 2016).

This integration has enabled the plotting of offence location to be recorded for further study on a single network platform. Though SCMS utilised network-based server for a real-time processing, this would require a remote core-processing server as to meet demand. However, the web structure has enabled FDTCP to reduce its dependence or having its own server, thus it is translated into costs saving benefits. The system helps the RMP by providing data to analysis, identified and formulating a measure of crime prevention.

The integration is forecasted to promote approximately RM15 million in saving of the government expenditures. On the other hand, Amandus has mentioned "Agencies are seen working in silos and doing their own activities to combat crimes. This system allows the community to orchestrate its efforts towards determining the allocation of funds for resources, such as CCTVs and the RMP strategically mobilise the task force grid.". Meanwhile, Senior Assistant Commissioner of the Royal Malaysian Police, Dato' Zainal Abidin Bin Kasim highlights that the "aoristic, 'timeline' and 'hotspot' SCMS is featured as the vital element in enabling RMP to refine a plan in optimising the resources and respond to certain crimes and hotspot areas." Vehicle theft, for example, is one of the most common crimes recorded in the system with the accumulated data of vehicle theft occurrences, has enabled them to closely monitor and derive plan of action in mobilizing the team. In accordingly, vehicle-theft-related incidents embrace underhanded activities by illegal workshops. He added that by "utilising the SCMS for planning, organizing and derive crime preventive measure, the 'Omnipresence programme' is magnified and engages the communities in raising awareness on issues concerning public safety." Furthermore, he added that because of well-informed planning, the RMP was able to make significant progress in reducing crime rates in about 50 local authorities.

Public perception towards the performance of the Police Force and the safety of their community has greatly improved. "This inter-agency collaboration is achieving its goals of providing citizens with the 'peace of mind' that we are keeping neighbourhoods safe by taking smarter approaches to public safety and security, allowing the police force to better respond and anticipate events, and if possible, prevent untoward incidents from happening." Dato' Zainal shared his view because of the benefits derived from using the SCMS in crime response and analysis, the government is looking into extending this capability to the Narcotics and Traffic Divisions soon to further improve their efforts in tracking locations and activities of drug dealers and to improve the police force's response during road emergencies.

There is an increasing trend of the offence from pre-independence to date. This trend has grown from humble beginnings as an ordinary theft, physical harm caused by confrontation and robbery on the street, to the crime syndicate and now a borderless crime that is more complex. Crime has become more complicated and sometimes impossible to detect. White-collar crime has taken a new turn since this crime has become a trans-border transactions involving thousands of miles and causing problems in the jurisdiction. Meanwhile, the crime in Malaysia has shown staggering rates of 
increase of has grown tremendously, and according to Tang (2011) it is very significant to start an experimental study to investigate the crime behaviour in Malaysia.

Criminals have taken the following way to improve themselves with knowledge in the matters under investigation. This situation led to the work of police forensic investigators more difficult. Now, as we know, there are many types of crime, as if to evolve with every minute of our speech. So how police forces in the world set their standards so they can be compared with other countries. Malaysia as a member of the international police community uses the phrase 'index crime' to measure crime. Index crimes are defined as: crimes that are reported with sufficient regularity and with sufficient interest to be understood as an index to the crime.

\section{Cooperation to Reduce Crimes Community Involvement}

The community needs to reduce the number of reports of serious criminal cases. The focus is on street crime such as burglary. The key word here is sufficient regularity and with sufficient interest. Therefore, in common parlance, the crime index refers to problems that often and usually involved in crime. As the explanatory note, kidnapping is quite unusual even this severe crime - it does not include the statistics in the index. Apart from it, even relatively small thefts are reflected in the index. This may sound a bit confusing to the listener but it worth noted that the ultimate motive Index Crime matrixes is to give a general idea of criminal activities in a country, and this index can be the basis of comparisons with other nations (Sidhu Singh Amar, 2005).

Dietz (1997) has argued reduction of fear of crime has associated with community policing programmes since their inception. Chataway, M.L \& Hart, T.C (2016) has found that Australian residents' perceptions of the neighbourhoods in which they live are believed to affect attitudes about crime and are consistent with social-psychological models of crime fear.

\section{Public Awareness}

Public and private sector partnership has set up a laboratory, after studying various proposals for several weeks. These sectors have put forward a strategy for cooperation between the people and government for the next two to three years. Enhancements in health care will be devoted to addressing the needs, improving the delivery of poor health to improve competence and efficiency, and cooperation with the Non-Government Organization and a private firm. To newlywed, people with low income as well as middle income will keep on benefits from the housing program. The aims of endeavour in crime prevention is the improvement of cooperation among the party's stakeholders from the public and private sectors, improve the ability of the enforcement body and streamlining the rule, and force enhancement. Also, a new initiative to improve traffic safety and first aid services will be presented.

The multi-ratio interaction platform has strengthened the effort toward social cohesion and national unity. To create more agendas to foster ethical and positive moral values will be introduced in the educational system. The government also stress on the involvement of the mass sports Emphasis will be given to participation in the development of mass sports and talented sportsman and develop leadership skill in athletic and activities linked to games. 


\section{Employment with Organization}

Employment together with reinforcing the excellent organization of professional law enforcement, particularly the police, the public confidence shall be achieved. As part of these efforts, the crime lab has conducted workshops with the participation of more than 30 government agencies and selected NGOs. Step coordinate these organisations, leading to cooperation within the community with a proposal that they provide. During the workshop, which is provided as a guideline to be implemented by the Government. At the end of this session, 55 together with the initiatives put forward five key performance indicators (KPI's). Among these efforts, a total of 29 initiatives related to the Royal Malaysian Police and the rest involve other organizations. Five Key Performance Indicators (KPI's) that is mentioned is to reduce cases of crime reported by 5 percent by 2010, reduce street crime (theft and burglary) by 20 per cent in 2010, reducing the fear of becoming a victim of crime, increasing the number violent crime offenders brought to justice, and improve public satisfaction with police performance. On the other hand, the rate of safety is high in the community that enforces the community policing, and the role of community policing is significant in problem solving due to security factors (Jiao,1999).

\section{Conclusion}

The development plan focuses the integration efforts through five main zones, specifically legislation and policies, ethos, adolescence and comprehensive improvement. In order to increase social cohesion and national unity, a number of community programmes are executed to strengthen public incorporation, foster an essence of forbearance and a greater union between Malaysia citizens.

JPNIN has conducted approximate 875,500 collaboration actions with social organisations and programmes such as Rukun Negara, Rukun Negara Secretariat, Community Integration, Social Networking, Cross Cultural and Inter-Religious Understanding (Abdul Sadat, 2016). The programmes are implemented through cooperation between government agencies, private sectors, and NGOs. A number of inventiveness is implemented to foster volunteerism among the youths. In this regards, 1Malaysia for Youth (iM4U) is established in 2012 as an NGO that advocates a number of community activities with the collaboration of residents such as iM4U Flood Relief, Volunteer Malaysia, and Reach out Convention and Celebration.

\section{Acknowledgement}

This project is funding by National Defence University of Malaysia.

\section{Corresponding Author}

Jessica Ong Hai Liaw, Assoc. Prof Dr, Email: jessica@upnm.edu.my, Faculty of Defense Studies and Management National Defense University of Malaysia, Malaysia. 
INTERNATIONAL JOURNAL OF ACADEMIC RESEARCH IN BUSINESS AND SOCIAL SCIENCES

Vol. 9, No. 1, Feb, 2019, E-ISSN: 2222-6990 @ 2019 HRMARS

\section{References}

Rahman, A. S. A. (2016). Unpublished Journal of the Evaluation on the Effectiveness of Crime Reducing Program by Uniform Bodies and Government Agency.

Liaw, J. O. H., Wong, W. ., Singh, I. S. T., Ridzuan, A. A., Moiden, A. H., Mohaiyadin, N. M., \& Rahiman, A. S. A. (2019). The Review of Effectiveness Integration Programs to Reduce Crime in Malaysia. International Journal of Academic Research Business and Social Sciences, 9(2), 12331244. 